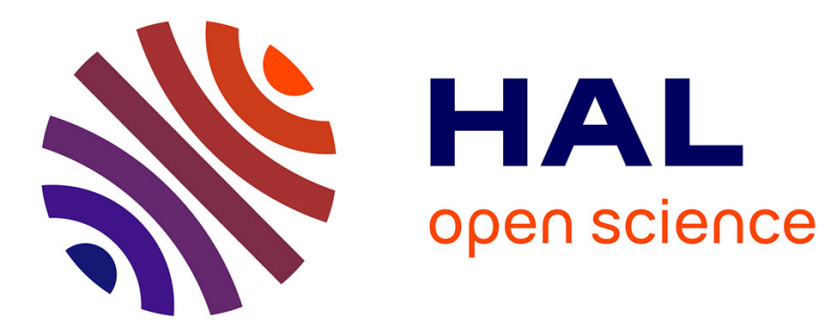

\title{
High or low fructose? Consequences for sugar metabolism in peach fruit
}

Elsa Desnoues, Yves Y. Gibon, Valentina Baldazzi, Veronique Signoret, Michel M. Génard, Bénédicte Quilot-Turion

\section{- To cite this version:}

Elsa Desnoues, Yves Y. Gibon, Valentina Baldazzi, Veronique Signoret, Michel M. Génard, et al.. High or low fructose? Consequences for sugar metabolism in peach fruit. 8. ISHS International Peach Symposium, Jun 2013, Matera, Italy. 1 p. hal-02740591

\section{HAL Id: hal-02740591 https://hal.inrae.fr/hal-02740591}

Submitted on 2 Jun 2020

HAL is a multi-disciplinary open access archive for the deposit and dissemination of scientific research documents, whether they are published or not. The documents may come from teaching and research institutions in France or abroad, or from public or private research centers.
L'archive ouverte pluridisciplinaire HAL, est destinée au dépôt et à la diffusion de documents scientifiques de niveau recherche, publiés ou non, émanant des établissements d'enseignement et de recherche français ou étrangers, des laboratoires publics ou privés. 


\title{
High or low fructose? Consequences for sugar metabolism in peach fruit
}

\author{
Elsa Desnoues ${ }^{1,3}$, Yves Gibon ${ }^{2}$, Valentina Baldazzi ${ }^{3}$, Véronique Signoret ${ }^{1}$, Michel \\ Génard $^{3}$, Bénédicte Quilot-Turion ${ }^{1}$
}

${ }^{1}$ INRA, UR1052 Génétique et Amélioration des Fruits et Légumes F-84143 Montfavet, France, ${ }^{2}$ INRA, UMR1332 Fruit Biology and Pathology F-33883 Villenave d'Ornon, France, ${ }^{3}$ INRA, UR1115 Plantes et Systèmes de culture Horticoles F-84914 Avignon, France

Fruit taste is largely affected by the content of soluble sugars and organic acids. Fructose is the sweetest tasting sugar. In commercial peach fruit, sucrose is the main sugar, followed by fructose and glucose which have similar levels. Interestingly low fructose accessions have been described in wild peaches. They display low fructose/glucose ratio. Two hypotheses can explain this fructose deficiency: reduced synthesis or increased degradation. Through an extensive profiling of metabolites and enzymatic activities, this study aims at i) describing sugar metabolism in peach fruit along fruit growth and ii) comparing two genotypes with contrasted fructose/glucose ratios. We measured 10 metabolites and 12 enzyme activities during fruit growth, for two genotypes over two years. Such a complete profiling of sugar metabolism along fruit growth has never been performed before for peach fruit. Genotypic and year effects are observed for all metabolites, whereas a majority of the enzymatic activities are stable between genotypes and years. More specifically, no difference is detected between the two genotypes in the activities of the enzymes responsible for synthesis or degradation of fructose. In addition, fructose concentration cannot be predicted from enzymatic activities. Finally, our results reveal a highly regulated system in which a major perturbation in a central compound has only slight repercussions on sugar metabolism. Further explanations for the low fructose phenotype are discussed, such as limited fructose storage resulting in higher degradation or a differential consumption of the two hexoses for respiration, synthesis of cell wall or other carbon compounds. To test the different hypotheses, a kinetic model of sugar metabolism was built on the basis of the profiling data. This model allows simulating sugar accumulation in peach fruit for both standard and low fructose phenotypes.

Corresponding Author: Elsa Desnoues, elsa.desnoues@avignon.inra.fr

I/We would prefer to present this study as ORAL PRESENTATION 